\title{
An Investigation of Groundwater Monitoring in Zimba District. Towards Sustainable Rural Groundwater Development and Management
}

\author{
Innocent C. Chomba \\ Ministry of Energy and Water Development, Zimba District
}

\begin{abstract}
Groundwater supplies over 70\% of Africa's water supply systems; both economic development and poverty reduction imperatives drive the development of groundwater resources across Africa (Adelana \& MacDonald, 2008). The demand for water in Zimba district has increased proportional to population growth and increased economic activities from the time it was declared a district in 2012. The aim of this study was to find out the number of existing groundwater monitoring boreholes and the type of data been collected in those monitoring points in Zimba District from 2013 to 2016. The results of this study revealed that Zimba district with an area of 5,245.01 $\mathrm{Km}^{2}$ in size has only one groundwater observation borehole that was drilled in 2012 and all the streams in the district are non perennial. The study also revealed that the data that is been collected for groundwater monitoring on the existing observation borehole is only limited to groundwater level. Additionally, water quality measurement is not been done at this observation borehole. It is concluded that for a sustainable underground water development to take place, there is need to identify and establish more groundwater monitoring points in the district in order to achieve sustainable groundwater development for rural communities.
\end{abstract}

Keywords: water, borehole, sustainable development, hydrology

\section{INTRODUCTION}

Reliable assessment of groundwater resources, required to supply rapidly growing populations in Africa under a changing climate, places extraordinary demands upon the field of hydrogeology. The limited knowledge of groundwater resources on a national scale hampers development and managed use of this resource in many countries of Africa. Effective management of Africa's groundwater resources is therefore challenging under these conditions and requires improved monitoring of groundwater resources (Adelana, 2009). The demand for water in Zimba district has increased proportional to population growth and increased economic activities from the time it was declared a district in 2012. Poor access to water especially in the dry season worsens the welfare situation of rural communities in Zimba District. Surface water and underground water are the main sources of water in the district however; all the streams are non-perennial as such the only way water is being harvested is through small dams which usually dry out in dry season and boreholes of which these are not present in every community.

Water in Zambia is not evenly distributed. The majority of the population still lack access to good drinking water and sanitation especially in rural settings like Zimba District. Water quality also varies in the country. Generally there is enough water in Zambia to meet the present demand, but water resources needs to be developed if it has to meet the demand for domestic use, water for irrigation, energy, fishery and mining. Surface water is however unevenly distributed within the country and there are often shortages in the southern parts of the country where Zimba District is located. Most of the surface water is within the major rivers of the Zambezi, Kafue, Luangwa, Luapula and Chambeshi, and lakes of Tanganyika, Bangweulu, Mweru, Mweru-wa-Ntipa, Kariba and Itezhi-tezhi. The main source of renewable water in Zambia is rainfall, but due to high temperature and high evapo-transpiration the country has a precipitation deficit of 100 to $1,100 \mathrm{~mm}$. Usually, this leads to high water losses especially from reservoirs such as lakes and dams. This means only about 3 to 12 percent of the rainfall can be considered as renewable water.

The Water Act 1948 is the Zambia's first legislation on water resources. However, the Water Act 1948 did not enforce effectively in the areas that it did not cover and did not apply to underground 
water protection, management and development. This prompted the Government to enact 2011 Water Act to include underground water protection, management and development. The value added by this Act is yet to come to full fruition. Currently, with the new water Act 2011 now in full force, groundwater development is rapidly been developed in most rural parts of Zambia. The aim of this study was to find out the number of groundwater monitoring point and the type of data been collected in those assessment points in Zimba District of Zambia for sustainable underground water development and management.

\section{The STUdy AREA}

Zimba district is located in Southern Province of Zambia, it lies between $17^{\circ}$ and $18^{\circ}$ Latitudes South and $26^{\circ}$ and $27^{\circ}$ Longitudes East. The district covers approximately a total area of 5,245.01 square kilometers in size. Zimba is one of the thirteen (13) districts of the Southern Province in Zambia. Zimba is predominantly rural area sharing boundary with Kalomo to the East, Kazungula to the South West. The district also shares an international border with Zimbabwe through the Zambezi River. For more than a decade Zimba District and Southern Province in general has suffered a reduction in rainfall, which has impacted on farming, nutrition, surface water, groundwater supplies and the economy in general. Zimba District has an average annual rainfall of about $700 \mathrm{~mm}$, and suffers from water shortages and droughts. Surface water is the main sources of water in the district (Figure 1: Zimba Drainage System). However, all the inland streams are non- perennial as such the only way water is being harvested is through dams which usually dry out in dry season and boreholes of which these are not present in every community. And most dams were built in 1960s and have since silted up and their holding capacity has reduced. Sedimentation is one of the factors that directly affect the performance of dams due to the resultant reduction of storage capacity (Chomba and Sichingabula, 2015).

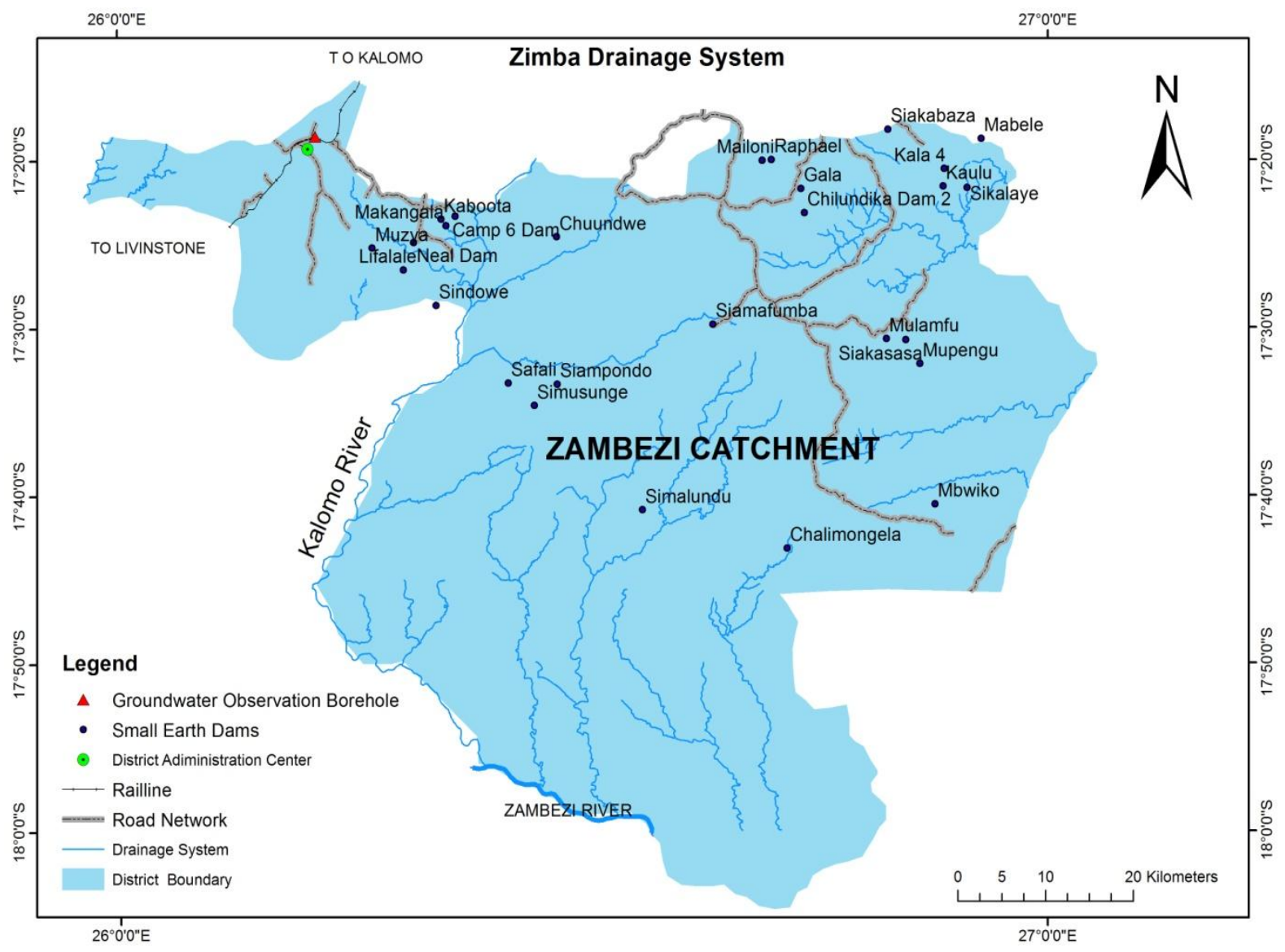

Figure2.1. Zimba drainage System

The Population for Zimba district is approximately 85,000 (CSO, 2016). The economy of the district is mainly dependent on agriculture $85 \%$ of the Population in Zimba depend on agriculture for livelihood thus sustainable water development and management is key. Economically, Zimba district is rated among the poorest districts in the country. To this effect, the poverty scenario in Zimba is basically attributed to many factors among which lack of access to clean water and sanitation. 


\section{Methodology}

The number of existing and functioning monitoring groundwater monitoring boreholes was collected from the Key informant from the Water Resources Management Authority (WARMA) which is tasked with groundwater monitoring and management in Zambia. This was followed by field visits and observation. The level of water table was collected from the field officer for WARMA who is stationed at the observation underground water point. The groundwater table levels were measured using WE501 Series Dipmeter (water level indicator). A log book was used to enter the daily water table depth for four (4) consecutive years from January 2013 to December 2016. The dipmeter is used for fast and accurate measurement of water levels in groundwater areas. The type of data collected was collected using a questionnaire from the WARMA officer stationed at the observation point. Microsoft 2017 excel was used to develop monthly variation graphs of groundwater depth from the monthly water depth averages computed in Microsoft excel 2007.

\section{RESUlTS AND DISCUSSION}

The results of this study revealed that Zimba district with an area of 5,245.01 $\mathrm{Km}^{2}$ in size has only one groundwater observation borehole that was drilled in 2008 but groundwater depth monitoring commenced in May 2012 and all the streams in the district are non perennial. The network of groundwater monitoring boreholes is not in existence. Samaranayake (2017) argue that monitoring networks for groundwater are necessary for development of groundwater resources, controlling groundwater hazards such as pollution, saltwater intrusion and remediation of contaminated subsurface. A properly designed monitoring network is therefore necessary to obtain the required information in a timely and cost-effective manner. The most important aspects of the design of a monitoring network include: Network density: the number of observation wells and their location in three dimensions based on hydrogeological information available. Therefore, optimal utilisation and management of groundwater resources in Zimba will require improved capacity to assess groundwater potential and monitor trends, with a better understanding of aquifer functioning.

The key challenge in Zambia and in Zimba in particular is developing capacity to manage and monitor intensive groundwater use. Appropriate technology and sustainable financing are also critical management constraints. In order to achieve sustainable groundwater management and development in Zimba District, there is a need to establish a network for groundwater observation boreholes. According to Loucks (2000:3) sustainability in water resource management means, 'water resource systems that are managed to satisfy the changing demands put on them, now and on into the future, without system degradation.' This could partly be achieved through well designed monitoring system for groundwater resources. MacDonal, (2012) argue that in Africa, groundwater is the major source of drinking water and its use for irrigation is forecast to increase substantially to combat growing food insecurity. Despite this, there is little quantitative information on groundwater resources in Africa, and groundwater storage is consequently omitted from assessments of freshwater availability.

The study also revealed that the data that is been collected for groundwater monitoring on the existing observation borehole is only limited to groundwater level. Figure 4(a)(b)(c)(d) shows the average monthly variation of groundwater level for four consecutive years (2013 to 2016) of depth measurements at the existing observation borehole. Unfortunately, water quality measurement is not been done at this observation borehole. One of the primary purposes of groundwater monitoring systems is to monitor the flow characteristics and the quality of groundwater. Periodic groundwater level measurements at various locations are essential for assessing the flow characteristics. Information on flow direction, flow velocity, and temporal water table fluctuation is necessary for groundwater modelling. Similarly, water quality monitoring should be performed to assess the magnitude of contamination or the rate of contaminant migration in groundwater (Samaranayake, 2017). Limited groundwater observational data in Zimba give rise to considerable uncertainty in broad, district statistics of freshwater availability and withdrawals.

Rural settlements in Zimba, nearly all depend on groundwater for safe drinking water supply and the demand has been increasing with increasing population. This growing dependence on groundwater calls for increased attention to groundwater development and careful management of the resource, thus requiring a well-structured monitoring programme and comprehensive data collection on different water parameters. Reliance of rural communities on groundwater is a common trend in most 
developing countries especially in sub-Saharan Africa, for example, Palamuleni and Akoth (2015) note that on a global scale, groundwater represents the world's largest and most important source of fresh potable water. Groundwater has proved to be the most reliable resource for meeting rural water demand in the sub-Saharan Africa. Due to inability of governments to meet the ever-increasing water demand, most people in rural areas resort to groundwater sources such as boreholes as an alternative water resource.

(a)

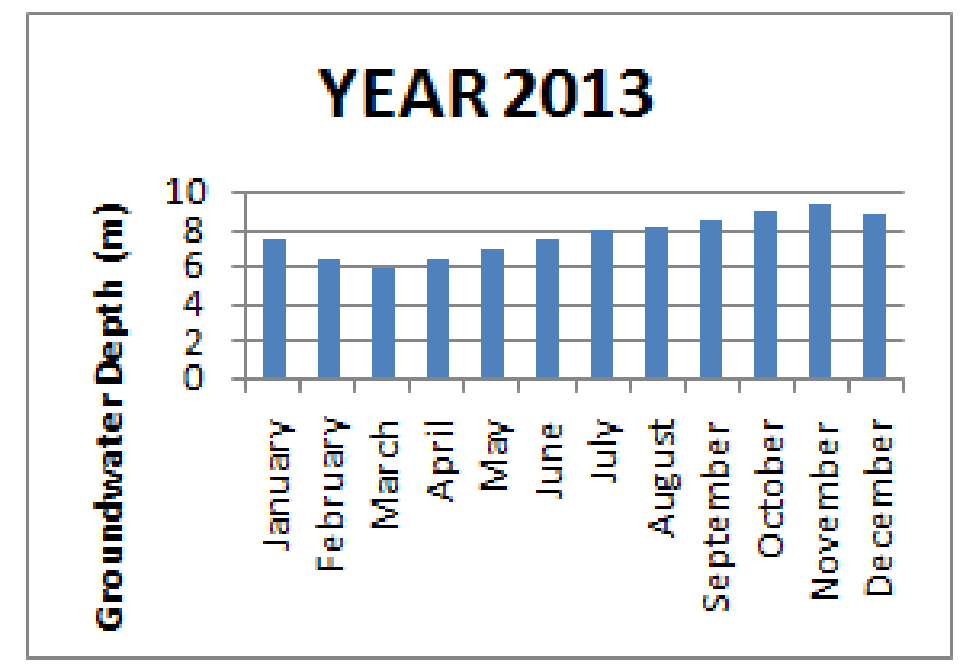

(b)

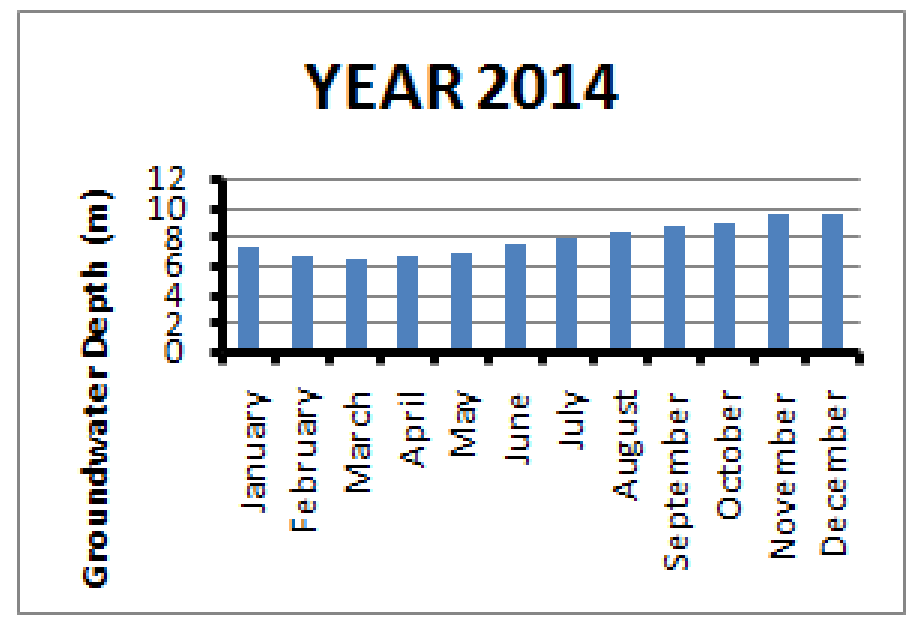

Figure4 (a) (b). Average monthly groundwater depth for years 2015 and 2016

(c)

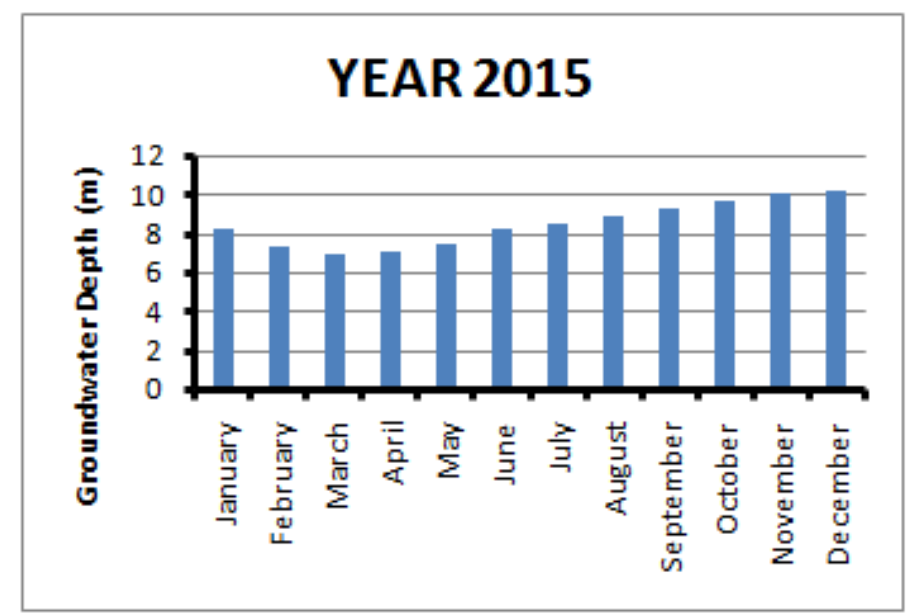


(d)

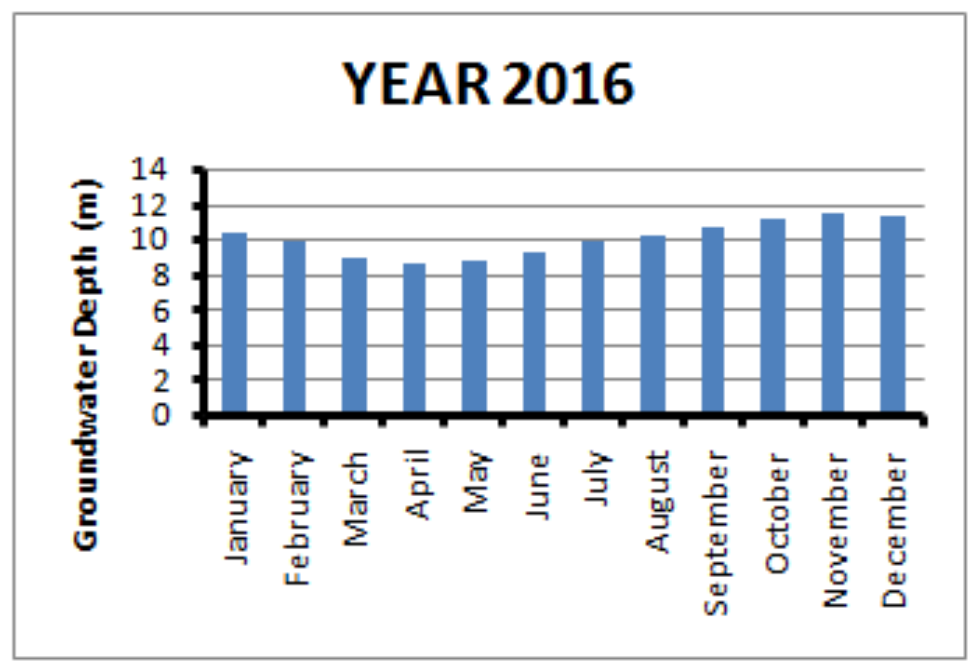

Figure4 (c) (d). Average monthly groundwater depth for years 2015 and 2016

\section{Conclusion}

The results of this study revealed that Zimba district with an area of $5,245.01 \mathrm{Km}^{2}$ in size has only one groundwater observation borehole that was drilled in 2012 and all the streams in the district are non perennial. The study also revealed that the data that is been collected for groundwater monitoring on the existing observation borehole is only limited to groundwater level. In addition, water quality measurement is not been done at this observation borehole. The demand for water in Zimba district is increasing, proportional to population growth and increased economic activities. Groundwater development intervention to improve the management and efficiency of water resources development in Zimba will require sufficient groundwater monitoring network data. It is concluded that for a sustainable groundwater development to take place, there is need to identify and establish more groundwater monitoring points in the district in order to achieve sustainable groundwater development for rural communities. And in addition to groundwater level data currently been collected, water quality and yield data should also be collected for sustainable groundwater development.

\section{ACKNOWLEDGMENT}

I acknowledge the unfailing guidance of Dr. Henry Sichingabula for his immensurable support, encouragement and academic guidance. As a result of his academic leadership, my previous research work has already been published in refereed journal: Chomba, I.C and Sichingabula, H M. (2015). 'Sedimentation and its Effects on Selected Small Dams East of Lusaka, Zambia'. Morden Environmental Science and Engineering. 1 (6) 325 -340. Doi 10.1534/ mese (23332581)/06.01.2015/007. Indeed without his great assistance, it would not have been easy to complete most of the research works I am doing. I am also indebted to Aaliyah Phelire Chomba, for playing a critical role in ensuring that this work is completed.

\section{REFERENCES}

Chomba, I. C and Sichingabula, H. M. (2015). Sedimentation and Its Effects on Selected Small Dams East of Lusaka, Zambia. Modern Environmental Science and Engineering. Vol.1., No. 4., pp.562577.

CSO, (2016). Projected Total Population and Number of Eligible Voters in the year 2016. Central Statistical Office. Lusaka

Adelana, S. M. A. (2009). Groundwater and Climate in Africa. (Proceedings of the Kampala Conference, June 2008) IAHS Publ. 334, 2009.

Adelana, S. M. A. \& MacDonald, A. M. (2008) Groundwater research issues in Africa. In: Applied Groundwater Studies in Africa. IAH Selected Papers on Hydrogeology, volume 13 (ed. by S. M. A. Adelana \& A. M. MacDonald). CRC Press/Balkema, Leiden, The Netherlands. 
Howard, K.W.F. Impacts of urban development on groundwater. In Environmental Geology of Urban Areas; Geotext 1997; Eyles, E., Ed.; Special Publication of the Geological Association of Canada: St. John's, Nfld, Canada, 1997; Volume 3, pp. 93-104

Loucks D.P. (2000). Sustainable water resources management. Water Int. 25 (1) 3-10.

MacDonal, M.A,.Bonsor, H.C., Dochartaigh, B.O and R G Taylor (2012). Quantitative maps of groundwater resources in Africa. Environmental Research Letters 7. 024009 7pp.

Palamuleni L and Akoth M (2015). Physico-Chemical and Microbial Analysis of Selected Borehole Water in Mahikeng, South Africa. International Journal of Environmental Research and Public Health. 12, 8619-8630.

Phiri, Z. (1999). Water Law, Water Rights and Water Supply Study Country Report -Zambia. Pp 7 and WRAP documents, Legislative Component.

Richard G. T., Antonis D. K And Callist T (2009). Groundwater and climate in Africa-a review.

Samaranayake, R., Hettiarachchige, D. G. and Islam, J. Groundwater Monitoring - Naresh Singhal. Environmental Monitoring-Vol.2.(http://www.eolss.net/Eolss-sampleAllChapter.aspx). Accessed on $16^{\text {th }}$ Febuary, 2017. 